\title{
Effects of Increase in the Cost of Building Materials on the Delivery of Affordable Housing in South Africa
}

\author{
Bimpe Alabi * and Julius Fapohunda
}

check for

updates

Citation: Alabi, B.; Fapohunda, J.

Effects of Increase in the Cost of Building Materials on the Delivery of Affordable Housing in South Africa. Sustainability 2021, 13, 1772. https:// doi.org/10.3390/su13041772

Received: 14 November 2020 Accepted: 1 January 2021

Published: 7 February 2021

Publisher's Note: MDPI stays neutral with regard to jurisdictional clai$\mathrm{ms}$ in published maps and institutional affiliations.

Copyright: (C) 2021 by the authors. Licensee MDPI, Basel, Switzerland. This article is an open access article distributed under the terms and conditions of the Creative Commons Attribution (CC BY) license (https:// creativecommons.org/licenses/by/ $4.0 /)$.
Department of Construction Management, Bellville Campus, Cape Peninsula University of Technology, Bellville 7535, South Africa; fapohundaj@cput.ac.za

* Correspondence: 213314460@mycput.ac.za or alabim2010@yahoo.com

\begin{abstract}
Adequate provision of affordable human settlements is a huge challenge in South Africa since its independence. This paper investigates the effects of the cost increase of building materials on affordable housing delivery in South Africa. With potential solutions for cost minimisation of building materials, with the aim of achieving affordable housing delivery in South Africa are provided. This study uses a sequential mixed methods approach, wherein surveys were conducted among the construction professionals (project managers, site managers architects, site engineers, quantity surveyors, contractors, building materials suppliers, and government workers) in the construction industry within Cape Town, South Africa, who were considered as the research participants. The qualitative data obtained from the survey exercise were analysed using content analysis, while the quantitative data were analysed using a descriptive statistical technique on SPSS. The findings attained show fluctuation in construction cost and a rise in maintenance cost (caused by poor workmanship) as significant effects in the cost increase of building materials for affordable housing delivery. Adequate application of the recommendations given in this study will minimise the effects of high cost of building materials and enhance affordable housing delivery. Appropriate handling of the findings given in this study will reduce the effects of the high cost of building materials and augment timely delivery of affordable housing and stakeholders' satisfaction.
\end{abstract}

Keywords: building materials; cost of materials; affordable housing; housing delivery

\section{Introduction}

Housing construction has developed in a remarkable way over the years. The desire for the welfare of the future generations is important [1]. With the purpose of easing pressure of improving housing provision across the globe, the integration of both sustainability and affordability was therefore considered as the potential approach towards housing provision [2]. This approach is referred to as sustainable affordable housing. Sustainable affordable housing is described as housing which satisfies the demand and needs of the present generation without compromising future generations' ability to meet their housing demands [3-5]. Alternatively, sustainable affordable housing can be defined simply as housing that is better planned and constructed, more durable, safe, significantly affordable, inexpensive to maintain, and has strong and inter-related economic, social and environmental components [6,7]. Appropriate, accessible, and sustainable housing is indispensable and it remains a basic need to the people. Thus, it needs to be available, affordable and durable continuously in the built environment [8].

Notwithstanding, to sustain the provision of affordable housing across South Africa, the housing construction industry should be more concerned about the economical handling of building materials cost. Building material or construction material is any material that can be used for the construction housing projects. It commonly includes steel, copper, cement, bitumen, lumber, masonry bricks/blocks, and sand among many others. The housing construction industry is one of the most important industries that underpins the economic development of a nation [9]. The construction sector impacts socio-economic 
expansion development in the developing countries by contributing substantially to their gross domestic product (GDP) [10,11]. As a result of this, it is crucial for the sector to understand the impact of the building materials cost in completing housing projects as scheduled. Building materials cost can actually comprise half (50\%) of the total cost of all projects executed by a construction industry [12]. Moreover, building materials cost depends on supply and demand, as well being affected by quality, quantity, time, place, buyer, and seller during a construction production [13]. Other factors are currency exchange, material specification, inflation pressure, and availability of new materials in the country [14]. Generally, total cost of executing a housing project is hugely affected by improper material handling on the construction site, and all this impacts the quality and time scheduled for a project to be completed [15]. Durdyev and Hosseini [16] conducted a survey and systematically reviewed studies on construction project delay; this revealed that the ten most common causes of this are climatic conditions, ineffective communication, deficiency in coordination and conflicts between stakeholders, improper planning, material shortages, financial problems, payment delays, equipment/plant shortage, lack required experience among project stakeholders, labour shortages, and poor site management.

According to some researchers, building materials play a pivotal role in building as a substantial input in the project development [17]. In South Africa, the incessant rising in price of building materials is a huge challenge towards the performance of the construction industry in delivering projects with quality and within the time scheduled [18]. The fluctuating market value for building materials tends to cause high project risk to all stakeholders (suppliers, contractors, and clients) involved in the construction production [19-21]. The demand for housing of all types, coupled with inflation and tight monetary supply, has caused a big challenge to the cost of building materials in the construction industry [22]. Therefore, an improved sustainable housing delivery within the budgeted time, cost, and expected quality, as well taking into consideration the stakeholders' satisfaction and cost of building materials, is absolutely essential. Sustainability is generally elaborated as a development that satisfies the needs of the current generation, without compromising future generations [2]. Therefore, to achieve the UN Sustainable Development goal, there is the need for a significant reduction in the cost of construction. As building materials contribute up to $50 \%$ of the cost of construction, there is a need to consider the factors which will minimise the excess cost of building materials Table 1 revealed variation in the construction material price index in South Africa between 2010 to 2018. These percentage increases are in line with overall inflation, as measured by the price index. Additionally, the survey of [18] revealed a diverse trend in the cost of building materials over the past two decades in South Africa (2001-2011). It appeared that the cost of building materials increased consistently yearly. Considering this, it is necessary to evaluate the effects of upsurge in the price of building materials on the delivery of affordable housing in South Africa.

Table 1. Selected construction materials price indices. Adapted by (BER 2019) [23].

\begin{tabular}{ccccccccccc}
\hline & $\mathbf{2 0 1 0}$ & $\mathbf{2 0 1 1}$ & $\mathbf{2 0 1 2}$ & $\mathbf{2 0 1 3}$ & $\mathbf{2 0 1 4}$ & $\mathbf{2 0 1 5}$ & $\mathbf{2 0 1 6}$ & $\mathbf{2 0 1 7}$ & $\mathbf{2 0 1 8}$ \\
\hline \multirow{2}{*}{ Earthwork (Index) \% Change } & 72.9 & 74.9 & 77.7 & 82.4 & 87.5 & 91 & 98.5 & 102.1 & 105.5 \\
& 1.4 & 2.7 & 3.7 & 6.2 & 6.2 & 4 & 8.3 & 3.6 & 3.2 \\
\hline Concrete (Excl Formwork) (Index) \% & 77.9 & 82.2 & 88.2 & 91.3 & 94.4 & 99.5 & 100.8 & 105 & 112.9 \\
Change & 4.7 & 5.6 & 7.2 & 3.5 & 3.4 & 5.4 & 1.3 & 4.2 & 7.6 \\
\hline \multirow{2}{*}{ Formwork (Index) \% Change } & 74.2 & 78.6 & 81.7 & 85.2 & 88.6 & 91.8 & 97.8 & 102.1 & 108 \\
& -0.2 & 5.9 & 4 & 4.3 & 4 & 3.5 & 6.6 & 4.4 & 5.8 \\
\hline \multirow{2}{*}{ Reinforcement (Index) \% Change } & 64.8 & 73.2 & 80.5 & 85.8 & 91.8 & 83.3 & 93.3 & 107.3 & 121.6 \\
& 1.2 & 12.8 & 10.1 & 6.5 & 3.5 & -9.3 & 12 & 15.1 & 13.3 \\
\hline
\end{tabular}


Table 1. Cont.

\begin{tabular}{cccccccccc}
\hline & $\mathbf{2 0 1 0}$ & $\mathbf{2 0 1 1}$ & $\mathbf{2 0 1 2}$ & $\mathbf{2 0 1 3}$ & $\mathbf{2 0 1 4}$ & $\mathbf{2 0 1 5}$ & $\mathbf{2 0 1 6}$ & $\mathbf{2 0 1 7}$ & $\mathbf{2 0 1 8}$ \\
\hline \multirow{2}{*}{ Brick and Block Work (Index) \% Changes } & 67.9 & 71.4 & 76.1 & 82 & 88 & 93.5 & 98.4 & 101.5 & 100.8 \\
& 4.9 & 5.1 & 6.7 & 7.7 & 7.4 & 6.2 & 5.3 & 3.2 & -0.7 \\
\hline \multirow{2}{*}{ Masonry (Index) \% Change } & 73.9 & 76.4 & 80.3 & 85.7 & 89.7 & 93.6 & 99.7 & 102.3 & 104.9 \\
& -0.3 & 3.4 & 5.2 & 6.6 & 8.5 & 3.8 & 6.5 & 2.6 & 2.6 \\
\hline Ceiling (Index) \% Change & 68.1 & 72.3 & 78.1 & 82.7 & 89.7 & 95.1 & 99.2 & 104.3 & 103.8 \\
& 6.1 & 6.1 & 8.1 & 5.9 & 8.5 & 6 & 4.3 & 5.2 & -0.5 \\
\hline Resilient Floor \& Wall Covering (Index) & 65.1 & 68.9 & 73.4 & 79.4 & 87.5 & 90.4 & 96.6 & 101.9 & 107.2 \\
Change \% & 7.6 & 5.8 & 6.5 & 8.2 & 10 & 3.5 & 6.8 & 5.4 & 5.2 \\
\hline
\end{tabular}

2. Effects of Increase in the Cost of Building Materials on Housing Delivery

\subsection{Fluctuation in Cost of Construction}

According to Windapo and Cattell [18], substantial growth in the construction industry is subject to the price stability in building materials. However, in South Africa, this price increases at higher rates than expected. Client and project contractors have been facing serious challenges to maintain steady cost projection on construction projects [17]. Ali and Kamaruzzaman [24] stated that poor estimation of original project cost and underestimating the construction cost by quantity surveyors are the basic reasons for cost escalation in the construction industry. The authors further stated that the prices change so quickly that the initial budget figures become completely unrealistic. A study on the implication of rising cost of building materials in Nigeria [17] identified fluctuation in construction costs as the major cause of increase in the cost of building materials. The above statement affirms the outcomes determined by [18] with regard to the key causes impacting the improvement of the construction industry in South Africa. The authors identified inflation as one of the key causes of the fluctuating cost of building materials, which affects construction industry development across the nation [18]. The impact of inflation on the cost of building materials results in low and unreliable rate of profitability, which renders the industrial performance areas inadequate, such as construction innovation, construction methods, and material research. Thus, this hinders the delivery of sustainable housing.

\subsection{Increase in Final Cost of Building Products}

Cost variation can be determined when the final cost of the project exceeds the original estimate cost. Lukale [25] and Ikechukwu et al. [26] defined cost variation as the variance between the original cost and the actual cost when the project is finished. From another perspective, cost variation can simply be described as the amount by which the actual costs surpass the accepted costs during the contract agreement [27]. To buttress this, [28] carried out a preliminary survey to determine the factors that cause cost variation in constructing wastewater projects in Egypt. Their findings identify the price fluctuation of materials as one of the important factors responsible for the variation of project costs [29]. According to Elinwa and Buba 1993 [29], as cited in [28], the considered cost of materials and variation of materials prices are the key factors causing a high final cost of building products in Nigeria.

\subsection{Increase in Project Abandonment}

Haseeb et al. [30] refers to the total abandonment of the construction project as stopping every work or suspending the project for a long time. Numerous construction projects are temporarily or permanently abandoned. However, the predominance of many uncompleted and abandoned projects was as a result of finance-related crisis and material related factors [30]. Ayodele and Alabi [31] and Idoro and Jolaiya [32] identified inflation and high cost of building materials as major factors that lead to uncompleted and sub-standard buildings. Clearly, high cost of building materials gives no room for industrial performance in the construction industry [15], while inflation is seen as the cause of progressive cost 
increase in building materials [18]. These two factors have huge impacts on sustainable housing delivery in South Africa [15,18,31,32].

Project abandonment is reported to promote negative environmental impacts. Aluko [33] stated that the effects of the abandoned project on the environment, identified as flooding problems, traffic congestion, air and water pollution, providing hideouts for drug addicts, and health hazards in the neighbourhood [33]. A study conducted by [17] revealed that an upward review of contract sum leads to conflicts between contractors and clients. This could lead to cases of abandonment, where investments are tied down, since such a project will not be put to use at the expected time.

\subsection{Low Volume of Construction Products}

The output of the construction industry in South Africa is quite low when compared with the construction industry in many developed countries. In view of this, it is understood that the South African construction industry is facing difficulties that decimate its performance across every aspect of its operations [9]. This effect leads to a low volume of construction products, and end-users are left to suffer from the inability of the government to provide adequate sustainable housing. In support of this Windapo et al. [34] elucidated that homeownership is priced out in the housing market due to the excessive increase in the building material cost. The result of this market situation is acute shortages of housing, which causes millions of middle-income and low-income earners to struggle to secure homeownership.

\subsection{Increase in Final Cost of Building Products}

Ikechukwu et al. [26] highlighted that the increase in the final cost of building product to end-users is as a result of impact of cost overruns in public building construction projects delivery. This effect inevitably gives rise to increased project cost, as caused by cost hike in construction materials [26].

\subsection{Poor Quality of Workmanship}

According to [35], the quality output of a building is one of the attributes of a developed construction industry. The quality of workmanship in construction works is assessed in accordance with the requirement of the relevant standard, and marks are awarded if the workmanship complies with the standard. The study performed by [14] envisaged a great risk in the construction industry and the nation's economy through the interpretation of the trend indicated in the cost of building materials. The authors further stated that there were records of conflicts between clients and building contractors over upward review in contract sums [14]. The avoidance of conflicts led to the use of substandard or insufficient supply of materials for construction projects. This is because some contractors try to boycott conflicts in order to be more productive in project completion within the budgeted time. The most distressing part of this action is that it can possibly cause a building to collapse, and people's lives will be at risk. Therefore, workmanship plays an important role in project quality [36]. Furthermore, Akanni et al. [17] pointed out that low quality of workmanship and inhibited innovations in construction methods are part of the problems caused by the escalation in the price of building materials. Hence, the study revealed that the increase in the cost of building material contributes to the low and unreliable rate of the profitability of contractors [17].

\subsection{Client Expectations on Quality Project Delivery}

Materials identification and construction detailing have a significant impact on the cost of the project. According to [37], the reliance of quality on cost is often expressed in the saying that goes as thus: "you get what you pay for". Cost has been considered as an indispensable factor in most building projects, and this causes some clients to seek low prices [19,38]. Unrealistic and inadequate budgets are often finance-driven in construction projects, wherein cheaper options are preferred to better or more sustainable alternatives. 
In some cases, certain clients may have fixed budgets that cannot be exceeded in any circumstances. In this case, clients expect the quantity surveyor to maintain rigorous cost control during project execution in order to deliver the project within budget. Designing to achieve such cost may result in excessive running and maintenance costs later on $[39,40]$.

\subsection{Collapse of Building Due to Less Quality Materials}

The purchase of poor-quality construction materials possibly causes building collapse. The use of such materials causes building inadequacy and unexpected accidents. Dimuna [41] and Amadi et al. [42] observed that building collapse is caused either by a natural factor or a man-made factor. The researchers further stated that developing nations suffer frequent collapse of buildings [41,42]. For example, a country like Nigeria suffers periodic collapse of buildings predominantly caused by man-made factors [41,42]. To buttress the above example, some studies were conducted few years ago by [43] to determine the key causes of building failure and collapse in Nigeria. The findings attained showed that sub-standard building materials remained a major issue to building collapse. Aziz [28] added that low quality building materials intensify the cost of construction above the actual projected cost due to the loss of material during the implementation phase. This could be termed as an effect of a lack of standards for materials.

\subsection{Unemployment of Construction Workers}

The construction industry's workers are extremely varied, consisting of skilled and unskilled workers [17]. Ayodele and Alabi [31] discovered that the impact of inflation in the cost of purchasing building materials is frustrating the industry, because many contractors are finding it difficult to accurately forecast the expected profit on the project. Thus, this situation contributes to the laying-off of workers and closure of firms in some extreme cases [31]. Oladipo and Oni [14] mentioned that the effects of macro-economic indicators on the cost of building materials contributed to unemployment. Furthermore, Oladipo and Oni [14] pointed out that employment reduction of workers in the construction industry may have an impact on a nation's GDP. In essence, the economical contribution of the construction industry to the nation's economy is decimated.

\subsection{High Rate of Contractors' Fraudulent Practices}

Project inflation is a common fraudulent practice among contractors. One of the project areas that is often inflated is the cost of purchasing building materials. This fraudulent practice can occur or recur at any point along the payment chain. It is understood that the class of workers in the bottom spot of the chain can perhaps inflate costs or the percentage of work completion. In that case, profit margin for these workers on the job will boost. Similarly, another section of the chain may try to exaggerate about costs to subs and suppliers, but fraudulently pocket their quota once a payment is made. The result of these illustrations is a potential multiple fluctuation of materials cost [44].

\section{Research Methodology}

To achieve the objective of this study, the sequential mixed methods approach posited by Teddie and Tashakkori [45] and Östlund et al. [46] were used. The process of the sequential mixed methods approach used is presented in Figure 1. 


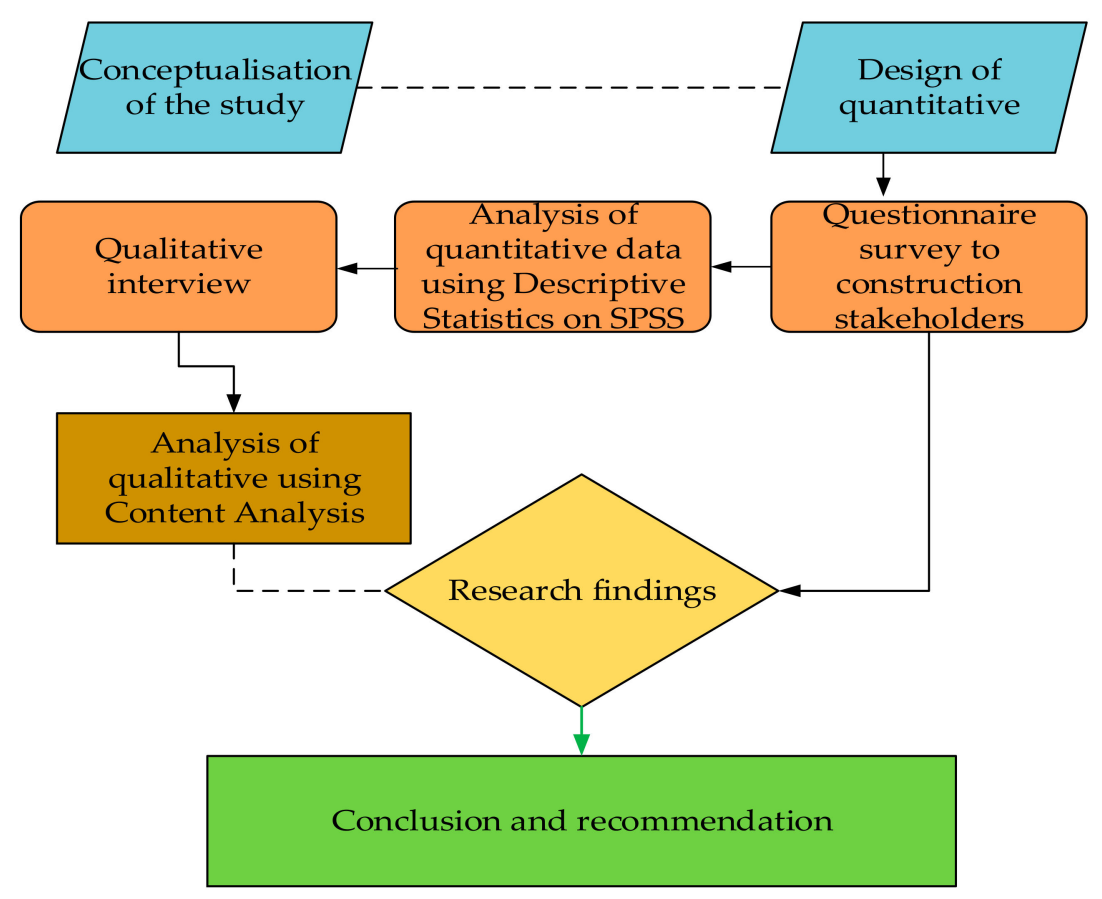

Figure 1. Sequence of method.

The cluster sampling method was used for data collection to redistribute the target population (with a high concentration of construction companies and experienced professionals) into smaller groups (clusters). These samples are randomly selected for data collection and result generalization. As such, construction managers, project managers, sales consultants, contractors, quantity surveyors, site managers, architects, and site engineers were involved. Questionnaires for the quantitative data were self-administered to guide and obtain opinions of the selected respondents.

After distributing the questionnaires, interviews were scheduled with construction industry professionals. The basic purpose of the interviews was to consolidate the questionnaire in acquiring relevant data for the purpose of the study. A total of 137 questionnaires were administered in person to construction stakeholders (architects, site engineers, project managers, quantity surveyors, contractors, building materials suppliers, site managers, and government workers) in the Western Cape Province. A total of 69 questionnaires were recovered and used for analysis. Quantitative data were analysed with the use of Statistical Package for Social Sciences (SPSS). A four-point Likert scale ranging from 1 (not at all) to 4 (to a very large extent) was adopted to capture the effects of the increase in the cost of building materials on housing delivery.

\subsection{Profile of Respondents}

Table 2 presents the positions held by survey participants. The largest groups of respondents $(20.3 \%)$ were project managers; quantity surveyors represented $17.4 \%$; site engineers, $11.6 \%$; construction managers, $13 \%$; $11.6 \%$, sales consultants; contractors, $7.2 \%$; site managers, $5.8 \%$; and architects, $13 \%$. In essence, the Table 2 data distribution indicates that the highest number of participations consisted of both quantity surveyors and project managers. Other respondents, such as construction managers, architects, sales consultants, and site engineers, also demonstrated participation, although in fewer quantities. This effect was achieved due to availability-based on time scheduling. 
Table 2. Position of respondents.

\begin{tabular}{ccc}
\hline Respondents (Position) & Quantity $(\boldsymbol{n})$ & Percentage (\%) \\
\hline Construction managers & 9 & 13.0 \\
Sales consultants & 8 & 11.6 \\
Contractors & 5 & 7.2 \\
Quantity surveyors & 12 & 17.4 \\
Site managers & 4 & 5.8 \\
Architects & 9 & 13.0 \\
Project managers & 14 & 20.3 \\
Site engineers & 8 & 12 \\
\hline Total & 69 & 100 \\
\hline
\end{tabular}

Likewise, the views of many construction professionals in the South African construction industry will improve the result consistency. The years of involvement of respondents in the industry are considerably adequate to achieve the purpose of the study. According to the figures arrayed in Table 3, 83\% of the respondents have over 10 years of work experience in the construction industry. However, this does not indicate that the contribution and experiences of the respondents within 1-5 years is not relevant in this study.

Table 3. Construction work experience level of the respondents.

\begin{tabular}{ccc}
\hline Work Experience (Years) & Quantity $(\boldsymbol{n})$ & Percentage $(\%)$ \\
\hline $1-5$ & 5 & 7.2 \\
$6-10$ & 7 & 10.1 \\
$11-15$ & 25 & 36.2 \\
$16-20$ & 15 & 21.7 \\
20 and above & 17 & 24.6 \\
\hline Total & 69 & 100 \\
\hline
\end{tabular}

In Table 4, 23 factors were considered and carefully evaluated in understanding the effects of the increase in the cost of building materials on housing delivery. The array of the factors in the table is in descending order of the mean values (MVs); that is, from the highest order of MVs to the lowest order of MVs. From the order of the MVs with 69 respondents, it was observed that only the last six factors exhibited MVs below 3.00, while others were within the MVs of 3.26-3.01. This array demonstrates that some factors have high impacts more than other factors, irrespective of their standard deviation (SD) values calculated. For instances, factors such as "fluctuation in cost of construction" (ranked 1, MV = 3.26) and "high maintenance cost due to poor workmanship" (ranked 2, MV =3.23) are extremely affected by the increase in the cost of building materials on housing delivery as indicated by respondents. This means that increase in the cost of building materials caused fluctuation in the cost of construction and high maintenance cost due to poor workmanship.

Additionally, some respondents indicated that increase in the cost of building materials caused "increase in cost of repair due to inferior materials used (ranked 3, MV = 3.19)", including poor workmanship (ranked $4, \mathrm{MV}=3.14$ ), client expectation's quality project delivery (ranked 5, MV = 3.11), collapse of building due to less quality materials (ranked 6, MV = 3.10), conflict between client and contractors due to upward review of contract sum (ranked 7, MV =3.10), delay in progress of project works (ranked 8, MV = 3.10), and other factors within 3.00. On the other hand, some respondents indicated that factors below MV of 3.00 are fairly affected by increase in the cost of building materials. 
Table 4. Effects of increase in the cost of building materials on housing delivery.

\begin{tabular}{|c|c|c|c|c|c|c|c|c|}
\hline Effects & Qty $(n)$ & 4 & 3 & 2 & 1 & MVs & SD & Rank (r) \\
\hline Fluctuation in cost of construction & 69 & 37.7 & 52.2 & 8.7 & 1.4 & 3.26 & 0.68 & 1 \\
\hline $\begin{array}{l}\text { High maintenance cost due to poor } \\
\text { workmanship }\end{array}$ & 69 & 36.2 & 50.7 & 13.0 & 0.0 & 3.23 & 0.67 & 2 \\
\hline $\begin{array}{l}\text { Increase in the cost of repair due to } \\
\text { inferior materials used }\end{array}$ & 69 & 31.9 & 56.5 & 10.1 & 1.4 & 3.19 & 0.67 & 3 \\
\hline Poor workmanship & 69 & 31.9 & 52.2 & 14.5 & 1.4 & 3.14 & 0.71 & 4 \\
\hline $\begin{array}{l}\text { Affect client expectation's on quality } \\
\text { project delivery }\end{array}$ & 69 & 33.3 & 46.4 & 18.8 & 1.4 & 3.11 & 0.75 & 5 \\
\hline $\begin{array}{l}\text { Building collapses due to the use of less } \\
\text { quality materials }\end{array}$ & 69 & 34.8 & 43.5 & 18.8 & 2.9 & 3.10 & 0.80 & 6 \\
\hline $\begin{array}{l}\text { Conflict between client and contractors } \\
\text { due to upward review of contract sum }\end{array}$ & 69 & 34.8 & 44.9 & 15.9 & 4.3 & 3.10 & 0.82 & 7 \\
\hline Delay on the progress of project works & 69 & 26.1 & 60.9 & 10.1 & 2.9 & 3.10 & 0.69 & 8 \\
\hline Poor quality of construction product & 69 & 21.7 & 65.2 & 13.0 & 0.0 & 3.09 & 0.58 & 9 \\
\hline $\begin{array}{l}\text { Increase in final cost of building } \\
\text { products, that is final cost of } \\
\text { production higher than budgeted }\end{array}$ & 69 & 31.9 & 47.8 & 15.9 & 4.3 & 3.07 & 0.81 & 10 \\
\hline $\begin{array}{l}\text { High rate of contractors' fraudulent } \\
\text { practices (inflating material costs) }\end{array}$ & 69 & 27.5 & 53.6 & 17.4 & 1.4 & 3.07 & 0.71 & 11 \\
\hline $\begin{array}{l}\text { End users are priced out for home } \\
\text { ownership due to high cost of building }\end{array}$ & 69 & 31.9 & 49.3 & 11.6 & 7.2 & 3.06 & 0.86 & 12 \\
\hline $\begin{array}{l}\text { Affect the aesthetics value of building } \\
\text { product }\end{array}$ & 69 & 20.3 & 65.2 & 13.0 & 1.4 & 3.04 & 0.63 & 13 \\
\hline $\begin{array}{l}\text { Shortage in the delivery of housing to } \\
\text { the populace }\end{array}$ & 69 & 29.0 & 50.7 & 15.9 & 4.3 & 3.04 & 0.79 & 14 \\
\hline $\begin{array}{l}\text { Affect gross domestic product (GDP) } \\
\text { contribution to the economy }\end{array}$ & 69 & 21.7 & 62.3 & 13.0 & 2.9 & 3.03 & 0.68 & 15 \\
\hline $\begin{array}{l}\text { Investment return on construction } \\
\text { project are delayed }\end{array}$ & 69 & 27.5 & 52.2 & 15.9 & 4.3 & 3.02 & 0.79 & 16 \\
\hline $\begin{array}{l}\text { Threating health as well as safety of } \\
\text { workers on site }\end{array}$ & 69 & 27.5 & 49.3 & 20.3 & 2.9 & 3.01 & 0.77 & 17 \\
\hline $\begin{array}{l}\text { Completion at the expense of other } \\
\text { projects }\end{array}$ & 69 & 23.2 & 50.7 & 24.6 & 1.4 & 2.96 & 0.74 & 18 \\
\hline Low volume of construction product & 69 & 17.9 & 60.9 & 20.3 & 1.4 & 2.94 & 0.66 & 19 \\
\hline $\begin{array}{l}\text { Transportation cost-e.g., returning } \\
\text { substandard materials to the supplier }\end{array}$ & 69 & 26.1 & 50.7 & 14.5 & 8.7 & 2.94 & 0.87 & 20 \\
\hline Increase in project abandonment & 69 & 21.7 & 47.8 & 27.5 & 2.9 & 2.88 & 0.78 & 21 \\
\hline $\begin{array}{l}\text { Hindered adequate implementation of } \\
\text { innovation in construction }\end{array}$ & 69 & 17.4 & 60.9 & 20.3 & 1.4 & 2.87 & 0.62 & 22 \\
\hline $\begin{array}{l}\text { Unemployment of construction } \\
\text { workers }\end{array}$ & 69 & 23.2 & 33.3 & 37.7 & 5.8 & 2.74 & 0.89 & 23 \\
\hline
\end{tabular}

\subsection{Analysis and Findings from Qualitative Studies}

Analysis of qualitative data across individual cases was conducted to evaluate the effects of increase in the cost of building materials on the delivery of affordable housing. Qualitative case study interviews were conducted with three selected housing developers and construction organisations in South Africa. Purposive sampling, as posited by [47,48], was used in determining information-rich participants whose understanding is important for the study. These interviews were transcribed and analysed using content analysis. Table 4 shows demographic of the respondents.

\subsubsection{Case Study 1}

Perception regarding the effects of increase in the cost of building materials on the delivery of affordable housing. The respondent, site supervisor emphasised that:

From experience, a common effect of increase in the cost of building materials is fluctuation; that is, in the sense that when material prices are not stable due to inflation, 
the contract or construction sum fluctuates, thereby affecting timely housing delivery to the populace. Conflict between client and contractor is also an effect of increase in the cost of building materials. Increase in the contract sum easily leads to disputes between involved stakeholders, leaving some disgruntled and dissatisfied.

The respondent pointed out relevant measures that can be taken into consideration to enhance sustainable housing delivery by advising South African government to ensure stable and viable regulations of the cost of building materials.

\subsubsection{Case Study 2}

Perception of project manager regarding the effects of increase in the cost of building materials on the delivery of affordable housing. The respondent stated that:

In my own opinion and experience in the construction industry, effects of increase in the cost of building materials are construction cost escalation, final cost production higher than budgeted and poor workmanship which in turn leads to high maintenance and repair cost. The respondent further stated that an increase in the cost of building materials has an adverse effect on client expectation of quality project delivery. In order to avoid conflict between clients and contractors, some contractors use substandard quality materials to meet the client budget requirement, and in this manner impact the client expectations of quality.

The project manager advised that the use of sustainable locally made building materials, rather than sophisticated building materials and techniques that are costly and energy consuming, should be encouraged by the government, as this will enhance affordable housing delivery. This will make the material cost effective and produce sustainable housing provisions.

\subsubsection{Case Study 3}

Perception of site manager regarding the effects of increase in the cost of building materials on the delivery of affordable housing. The respondent stressed that:

Increase in the cost of building materials has a massive effect on the timely delivery of housing. Building materials consume up to $60.0 \%$ of all construction costs. He further stated that increase in the cost of building materials will push the cost of construction higher than estimated project cost. Another effect, with my experience in the industry, is conflict between client and contractor due to the increase in project budgeted cost and delay in the progress of project works. The respondent further noted that late delivery of materials to site is the major cause of construction cost and time overrun.

The respondent suggested that in order to enhance sustainable housing delivery, some steps needs to be established. The availability of materials on site is very important, as this determines the speed at which the work is completed and will reduce materials wastage and cost towards economic sustainability. Table 5 shows the summary of findings of qualitative interviews.

Table 5. Summary of findings of qualitative interviews.

\begin{tabular}{cccc}
\hline Factor & Respondent 1 & Respondent 2 & Respondent 3 \\
\hline $\begin{array}{c}\text { Effects of building materials } \\
\text { cost on housing delivery }\end{array}$ & $\begin{array}{c}\text { Fluctuation in the cost of } \\
\text { construction and conflict } \\
\text { between client and contractor }\end{array}$ & $\begin{array}{c}\text { Construction cost escalation, } \\
\text { final cost of production higher } \\
\text { than budgeted and poor } \\
\text { workmanship which will in } \\
\text { turn leads to high } \\
\text { maintenance and repair cost }\end{array}$ & $\begin{array}{c}\text { Conflict between client and } \\
\text { in project budgeted cost and } \\
\text { delay on the progress of } \\
\text { project work }\end{array}$ \\
\hline
\end{tabular}

\section{Discussion of Findings}

The findings on the effect on housing delivery are discussed. Tables 3 and 4 provided numerical results of respondents' perceptions on the effects of increase in the cost of building materials on housing delivery. The findings reveal that the increase in the cost 
of building materials frustrates the progress of the construction industry in South Africa due to many affected factors, such as fluctuation in cost of construction, high maintenance cost due to poor workmanship, increase in the cost of repair due to inferior materials used, poor workmanship, and many others, as arrayed in Table 6. From the tabularised results, it is observed that "fluctuation in cost of construction" with a MV of 3.26 is the most affected. The client and project contractors have been facing serious issues to maintain steady cost projection on construction projects [17]. Therefore, cost control during the construction process is very important to ensure the success of a project [49]. Further findings indicated that high maintenance cost due to poor workmanship, increase in the cost of repair due to inferior materials used, poor workmanship, client expectation's on quality project delivery, and building collapses due to the use of less quality materials are all affected by increase in cost of building materials on housing delivery. Iwaro and Mwasha [36] highlighted that workmanship plays an important role in project's quality. One of the characteristics of a developed construction industry is in the output of quality buildings and structures [50]. However, Oyedele and Tham [51] posited that a lack of significant consideration for design constructability may cause building collapse during the construction process. Therefore, stakeholders' satisfaction and timely project completion has been a yardstick for measuring project success in relation to time, quality, scope and cost [52,53].

Table 6. Demographic of qualitative respondents.

\begin{tabular}{ccccc}
\hline Respondent & Qualification & Position & $\begin{array}{c}\text { Years of Experience in } \\
\text { Construction Industry }\end{array}$ & $\begin{array}{c}\text { Years of Experience in } \\
\text { the Present Position }\end{array}$ \\
\hline Case study 1 & Bachelor's degree & Site supervisor & 12 years & 8 years \\
\hline Case study 2 & Honour's degree & Project manager & 22 years & 9 years \\
\hline Case study 3 & Bachelor's degree & Site manager & 14 years & 5 years \\
\hline
\end{tabular}

\section{Conclusions and Recommendations}

Based on the findings from the study, it was understood that fluctuation in the cost of construction is a huge influence caused by increase in the cost of building materials on the delivery of affordable housing in Western Cape. The findings also revealed high maintenance cost due to poor workmanship and an increase in the cost of repair due to inferior materials used as other huge influences caused by the increase in the cost of building materials on housing delivery in Western Cape Province of South Africa.

With the purpose of guiding against excessive fluctuation in the cost of construction, stakeholders should have a well-developed plan for materials in advance to avoid the effect of the increase in building material prices in the market. Thus, proper planning and scheduling at the initial stages of construction are very essential, which includes the early purchase of building materials within the budgeted cost and suitable storage of building materials is to be adopted to avoid cost overrun, disputes, and inflation. If this could be the effect, it will enhance the timely delivery of housing at the budgeted cost specified and meeting client expectations. Affordable housing programs should also consider the economic sustainability of developers (e.g., the cost effectiveness of the projects) to ensure that these programs can be developed on a continuous basis, while developers can adopt cost reduction strategies (such as the use of regionally available materials and techniques), providing stable financial incentives is needed for developers to secure financial viability [54]. El-hadj et al. [55] revealed that value of architecture that is often ignored in the conception of affordable housing development project design can be enhanced. An enhanced architectural design can lower construction costs significantly, not only by reducing the quantity of material used, but also by minimising material waste. However, this could be achieved by limiting the number of corners or reducing the number of convex or concave corners reduces construction costs. 
Author Contributions: Conceptualization, B.A.; Methodology, B.A.; Software, B.A.; Validation, B.A.; Formal Analysis, B.A.; Investigation, B.A.; Resources, B.A.; Data Curation, B.A.; Writing-Original Draft Preparation, B.A.; Writing-Review \& Editing, B.A. and J.F.; Visualization, B.A.; Supervision, J.F. All authors have read and agreed to the published version of the manuscript.

Funding: The APC was funded by the Cape Peninsula University of Technology, South Africa.

Institutional Review Board Statement: Not applicable.

Informed Consent Statement: Not applicable.

Data Availability Statement: Not applicable.

Conflicts of Interest: The authors declare no conflict of interest.

\section{References}

1. Shen,, L.Y.; Ochoa, J.J.; Shah, M.N.; Zhang, X. The application of urban sustainability indicators-A comparison between various practices. Habitat Int. 2011, 35, 17-29. [CrossRef]

2. Golubchikov, O.; Badyina, A. Sustainable Housing for Sustainable Cities: A Policy Framework for Developing Countries; UN-HABITAT: Nairobi, Kenya, 2012.

3. DeLaTorre, A.K. Sustainable, Affordable Housing for Older Adults: A Case Study of Factors that Affect Development in Portland, Oregon; Portland State University: Portland, OR, USA, 2013.

4. Gan, X.; Zuo, J.; Wu, P.; Wang, J.; Chang, R.; Wen, T. How affordable housing becomes more sustainable? A stakeholder study. J. Clean. Prod. 2017, 162, 427-437. [CrossRef]

5. Adabre, M.A.; Chan, A.P. Critical success factors (CSFs) for sustainable affordable housing. Build. Environ. 2019, 156, 203-214. [CrossRef]

6. UN-Habitat (2011a) Condominium Housing in Ethiopia: The Integrated Housing Development Programme; United Nations Human Settlements Programme (UN-Habitat): Nairobi, Kenya, 2011.

7. Arman, M.; Zuo, J.; Wilson, L.; Zillante, G.; Pullen, S. Challenges of responding to sustainability with implications for affordable housing. Ecol. Econ. 2009, 68, 3034-3041. [CrossRef]

8. Ihuah, P.W. Building materials costs increases and sustainability in real estate development in Nigeria. Afr. J. Econ. Sustain. Dev. 2015, 4, 218-233. [CrossRef]

9. Ganiyu, B.O. Strategy to Enhance Sustainability in Affordable Housing Construction in South Africa. Ph.D. Thesis, Cape Peninsula University of Technology, Cape Town, South Africa, 2016.

10. Ofori, G. (Ed.) New Perspectives on Construction in Developing Countries; Routledge: Abingdon, UK, 2012.

11. Chen, W.; Chen, J.; Xu, D.; Liu, J.; Niu, N. Assessment of the practices and contributions of China's green industry to the socio-economic development. J. Clean. Prod. 2017, 153, 648-656. [CrossRef]

12. Caldas, C.H.; Menches, C.L.; Reyes, P.M.; Navarro, L.; Vargas, D.M. Materials management practices in the construction industry. Pract. Period. Struct. Des. Constr. 2015, 20, 04014039. [CrossRef]

13. San Ong, T. Factors affecting the price of housing in Malaysia. 2013. Available online: http://www.globalbizresearch.com/ images/files/73848_JEIEJB_\%20Tze\%20San,20 (accessed on 15 July 2020).

14. Oladipo, F.O.; Oni, O.J. Review of Selected Macroeconomic Factors Impacting Building Material Prices in Developing CountriesA Case of Nigeria. Ethiop. J. Environ. Stud. Manag. 2012, 5, 131-137. [CrossRef]

15. Ghoddousi, P.; Hosseini, M.R. A survey of the factors affecting the productivity of construction projects in Iran. Technol. Econ. Dev. Econ. 2012, 18, 99-116. [CrossRef]

16. Durdyev, S.; Hosseini, M.R. Causes of delays on construction projects: A comprehensive list. Int. J. Manag. Proj. Bus. 2019, 13, 20-46. [CrossRef]

17. Akanni, P.O.; Oke, A.E.; Omotilewa, O.J. Implications of Rising Cost of Building Materials in Lagos State Nigeria. SAGE Open 2014, 4, 2158244014561213. [CrossRef]

18. Windapo, A.; Cattell, K. Examine the Trends in Building Material Prices: Build Environment Stakeholders' Perpectives. In Proceedings of the Joint CIB International Sysposium of W055, W065 and W089, W118, TG46, TG81 and TG84. International Conference on Construction Management Research: Management of Construction-Research to Practice, Montreal, QC, Canada, 26-29 June 2012; ISBN 978-2-98133550-0-0.

19. Doloi, H.; Sawhney, A.; Iyer, K.C.; Rentala, S. Analysing factors affecting delays in Indian construction projects. Int. J. Proj. Manag. 2012, 30, 479-489. [CrossRef]

20. Dulaimi, M.F.; Alhashemi, M.; Ling, F.Y.Y.; Kumaraswamy, M. The execution of public-private partnership projects in the UAE. Constr. Manag. Econ. 2010, 28, 393-402. [CrossRef]

21. Ling, F.Y.Y.; Hoang, V.T.P. Political, economic, and legal risks faced in international projects: Case study of Vietnam. J. Prof. Issues Eng. Educ. Pract. 2010, 136, 156-164. [CrossRef]

22. Esohofonie, F.P. Factors Affecting Cost of Construction in Nigeria. Master's Thesis, University of Lagos, Lagos, Nigeria, 2008. Unpublished. 
23. Bureau of Economic Research (BER). Report on Building Costs-Quarterly Analysis of Building Cost; BER: Stellenbosch, South Africa, 2019.

24. Ali, A.S.; Kamaruzzaman, S.N. Cost performance for building construction projects in Klang Valley. J. Build. Perform. 2010, 1, 110-118.

25. Lukale, A.M. Determinants of Cost Overruns in Rural Roads Infrastructure Projects in Kenya. Ph.D. Thesis, Strathmore University, Nairobi, Kenya, 2018.

26. Ikechukwu, A.C.; Fidelis, I.; Kelvin, O.A. Causes and Effects of Cost Overruns in Public Building Construction Projects Delivery, In Imo State, Nigeria. IOSR J. Bus. Manag. 2017, 19, 13-20. [CrossRef]

27. Glaeser, E.L.; Gyourko, J.; Saks, R. Why is Manhattan so expensive? Regulation and the rise in housing prices. J. Law Econ. 2005, 48, 331-369. [CrossRef]

28. Aziz, R.F. Factors causing cost variation for constructing wastewater projects in Egypt. Alex. Eng. J. 2013, 52, 51-66. [CrossRef]

29. Elinwa, A.U.; Buba, S.A. Construction cost factors in Nigeria. J. Constr. Eng. Manag. 1993, 119, 698-713. [CrossRef]

30. Haseeb, M.; Lu, X.; Hoosen, A.B.; Rabbani, W. Causes and effects of delays in large construction projects of pakistan. Kuwait Chapter Arab. J. Bus. Manag. Rev. 2011, 1, 18-42.

31. Ayodele, E.O.; Alabi, O.M. Abandonment of construction projects in Nigeria: Causes and effects. J. Emerg. Trends Econ. Manag. Sci. 2011, 2, 142-145.

32. Idoro, G.I.; Jolaiya, O. Evaluating material storage strategies and their relationship with construction project performance. In Proceedings of the CIB International Conference on Building Education and Research, Cape Town, South Africa, 10-13 May 2010; University of Cape Town; pp. 103-110.

33. Aluko, O.O. Construction project abandonment in Nigeria: A Threat to National Economy. Knowl. Rev. 2008, 16, 18-23.

34. Windapo, A.O.; Ogunsanmi, O.E.; Iyagba, R.O. Modeling the Determinants of the Demand for Housing Construction in Nigeria. In Proceedings of the CIB W107 \& TG 23 International Symposium on Globalization and Construction, KlongLuang, Thailand, 17-19 November 2004; Ogunlana, S., Charoenngam, C., Herabat, P., Hadikusumo, B.H.W., Eds.; pp. 631-646.

35. Pacheco-Torgal, F. Eco-efficient construction and building materials research under the EU Framework Programme Horizon 2020. Constr. Build. Mater. 2014, 51, 151-162. [CrossRef]

36. Iwaro, J.; Mwasha, A. The effects of ISO certification on organization workmanship performance. Qual. Manag. J. 2012, 19, 53. [CrossRef]

37. Ruskin, J. Praeterita; Oxford University Press: New York, NY, USA, 2012.

38. Meng, X. The effect of relationship management on project performance in construction. Int. J. Proj. Manag. 2012, 30, 188-198. [CrossRef]

39. Nkhabu, L. The Effectiveness of Construction Project Management Services towards Clients' Objectives in the Building Industry; University of Pretoria: Pretoria, South Africa, 2011.

40. Smith, J.; Jaggar, D.M.; Love, P. Building Cost Planning for the Design Team; Routledge: Abingdon, UK, 2016.

41. Dimuna, K.O. Incessant Incidents of Building Collapse in Nigeria: A Challenge to Stakeholders. Glob. J. Res. Eng. 2010, 10, 75-84.

42. Amadi, A.N.; Eze, C.J.; Igwe, C.O.; Okunlola, I.A.; Okoye, N.O. Architect's and Geologist's View on the Causes of Building Failures in Nigeria. Mod. Appl. Sci. 2012, 6, 31.

43. Hamma-Adama, M.; Kouider, T. Causes of building failure and collapse in Nigeria: Professionals' view. Am. J. Eng. Res. 2017, 6, 289-300.

44. Alex, B. Construction Fraud: Common Issues and How to Combat Them. 2019. Available online: https://www.levelset.com/ blog/construction-fraud/\#article-author (accessed on 20 August 2019).

45. Teddie, C.; Tashakkori, A. Foundations of Mixed Methods Research: Integrating Quantitative and Qualitative Approached in the Social and Behavioral Sciences; Sage: London, UK, 2009.

46. Östlund, U.; Kidd, L.; Wengström, Y.; Rowa-Dewar, N. Combining qualitative and quantitative research within mixed method research designs: A methodological review. Int. J. Nurs. Stud. 2011, 48, 369-383. [CrossRef]

47. O'Leary, Z. The Essential Guide to Doing Your Research Project; Sage: New York, NY, USA, 2010.

48. Gentles, S.J.; Charles, C.; Ploeg, J.; McKibbon, K.A. Sampling in qualitative research: Insights from an overview of the methods literature. Qual. Rep. 2015, 20, 1772-1789.

49. Nega, F. Causes and Effects of Cost Overrun on Public Building Construction Projects in Ethiopia. Ph.D. Thesis, Addis Ababa University, Addis Ababa, Ethiopia, 2008. Unpublished.

50. Lam, P.T.; Chan, A.P.; Wong, F.K.; Wong, F.W. Constructability rankings of construction systems based on the analytical hierarchy process. J. Archit. Eng. 2007, 13, 36-43. [CrossRef]

51. Oyedele, O.; Tham, W. Client's assessment of architects' performance in building delivery process: Evidence from Nigeria. J. Build. Environ. 2006, 42, 2090-2099. [CrossRef]

52. Takim, R. The management of stakeholders' needs and expectations in the development of construction project in Malaysia. Mod. Appl. Sci. 2009, 3, 167-175. [CrossRef]

53. Aggor, K.K. Relationship between Budget and Project Success Factors in the Ghanaian Building Construction Sector; Walden University: Minneapolis, Minnesota, 2017.

54. Pullen, S.; Arman, M.; Zillante, G.; Zuo, J.; Chileshe, N.; Wilson, L. Developing an assessment framework for affordable and sustainable housing. Australas. J. Constr. Econ. Build. 2010, 10, 60.

55. El-hadj, M.B.; Faye, I.; Geh, Z.F. The construction cost conundrum in Africa. In Housing Market Dynamics in Africa; Palgrave Macmillan: London, UK, 2018; pp. 159-214. 